\title{
PENGARUH PEMBERDAYAAN APARATUR, PENGAWASAN DAN LINGKUNGAN KERJA TERHADAP PRODUKTIVITAS KERJA PEGAWAI DINAS PERPUSTAKAAN DAN KEARSIPAN KOTA TANJUNGBALAI
}

\author{
${ }^{1}$ Herna Rahmi, ${ }^{2}$ Novida Timoria Siregar, ${ }^{3}$ Evi Rahmwati \\ ${ }^{1,2,3}$ Universitas Islam Sumatera Utara \\ 1'herna.rahmi@gmail.com, ${ }^{2}$ novida.timora@gmail.com, ${ }^{3}$ evi.rahmawati@gmail.com,
}

\begin{abstract}
The formulation of the problem in this study is whether the empowerment of the apparatus, supervision and work environment simultaneously has a positive and significant effect on the work productivity of the employees at Library and Records Office, Kota Tanjungbalai. This study aims to determine the effect of apparatus empowerment, supervision and work environment on the work productivity of the employees at Library and Records Office, Kota Tanjungbalai. The sample in this study were all employees of the Office of Library and Archives of Tanjungbalai City, which numbered 38 people. The data analysis technique in this research is Multiple Linear Regression.

The results of this study indicate; Apparatus empowerment partially has a positive and significant effect on employee work productivity; Supervision partially has a positive and significant effect on employee work productivity; The work environment partially has a positive and significant effect on employee work productivity; Empowerment of the apparatus, supervision and work environment simultaneously has a positive and significant effect on employee work productivity.
\end{abstract}

Keywords : Apparatus Empowerment; Supervision; Work Environment; Work Productivity

ABSTRAK : Rumusan masalah dalam penelitian ini apakah pemberdayaan aparatur, pengawasan dan lingkungan kerja secara simultan berpengaruh positif dan signifikan terhadap produktivitas kerja pegawai Dinas Perpustakaan Dan Kearsipan Kota Tanjungbalai. Penelitian ini bertujuan untuk mengetahui pengaruh pemberdayaan aparatur, pengawasan dan lingkungan kerja terhadap produktivitas kerja pegawai Dinas Perpustakaan Dan Kearsipan Kota Tanjungbalai. Sampel dalam penelitian ini adalah seluruh pegawai Dinas Perpustakaan Dan Kearsipan Kota Tanjungbalai yang berjumlah 38 orang. Teknik analisis data dalam penelitian ini adalah Regresi Linier Berganda. Hasil penelitian ini menunjukkan; Pemberdayaan aparatur secara parsial berpengaruh positif dan signifikan terhadap produktivitas kerja pegawai; Pengawasan secara parsial berpengaruh positif dan signifikan terhadap produktivitas kerja pegawai; Lingkungan kerja secara parsial berpengaruh positif dan signifikan terhadap produktivitas kerja pegawai; Pemberdayaan aparatur, pengawasan dan lingkungan kerja secara simultan berpengaruh positif dan signifikan terhadap produktivitas kerja pegawai.

Kata Kunci : Pemberdayaan Aparatur; Pengawasan; Lingkungan Kerja; Produktivitas Kerja

\section{Pendahuluan}

Pada dasarnya setiap instansi yang didirikan mempunyai harapan bahwa kelak di kemudian hari akan mengalami perkembangan yang pesat di dalam lingkup kegiatannya dan menginginkan terciptanya produktivitas yang tinggi dalam bidang pekerjaannya. Untuk mewujudkan operasinya tersebut dibutuhkan beberapa faktor produksi yaitu, tenaga kerja, modal, dan keahlian, dimana keempat faktor tersebut tidak dapat berdiri sendiri, melainkan harus saling mendukung untuk mencapai tujuan secara efektif dan efisisen dam diantara keempat faktor utama tersebut faktor tenaga kerja atau manusia dalam hal ini adalah pegawai, merupakan hal yang terpenting karena manusia merupakan pemakai dan penggerak serta penentu dari semua aktivitas.

Produktivitas kerja pegawai pada sebuah organisasi merupakan masalah yang selalu hangat dan tidak ada habis-habisnya untuk dibahas. Permasalahan yang terkait dalam produktifitas juga merupakan isu strategis bagi organisasi yang memprogram masalah sumber 
daya manusia. Banyak aspek intenal dan eksternal yang mendukung terciptanya produktivitas kerja yang efektif dan efisien dalam suatu organisasi. Apalagi bila dikaitkan dengan masalah globalisasi yang melanda saat ini yang dampaknya sangat kita rasakan.

Peningkatan produktivitas sumber daya manusia merupakan pembaharuan pandangan hidup yang memuliakan kerja demi untuk meningkatkan kualitas hidup dengan falsafah bahwa hari esok lebih baik dari hari ini. Untuk itu maka harus selalu diusahakan peningkatan hasil dan mutu kerja.

Seorang pemimpin dalam sebuah organisasi mempunyai tanggung jawaab untuk meyakinkan anggotanya akan perlunya ditumbuhkan, dikembangkan dan dipraktekkan hubungan kerja sama yang sehat diantara anggota organisasi sehingga akan mendorong anggota untuk bekerja sama dengan produktif dan dengan perasaan puas. Hal ini sesuai dengan tugas seorang pemimpin yaitu mendorong kerja sama secara sukarela diantara pegawai dan dengan pimpinan dalam melaksanakan tugas pekerjaannya.

Menurut Hasibuan dalam Teguh (2016: 15) produktivitas kerja adalah meningkatnya output (hasil) yang sejalan dengan input (masukan). Jika produktivitas naik ini hanya dimungkinkan oleh adanya peningkatan efisiensi (waktu, bahan, tenaga) dan sistem kerja, teknik produksi dan adanya peningkatan keterampilan dari tenaga kerjanya.

Fenomena yang terjadi di Dinas Perpustakaan Dan Kearsipan Kota Tanjungbalai dalam usaha meningkatkan produktivitas kerja belum sesuai dengan target yang telah ditentukan oleh organisasi. Hal ini terlihat dari kemampuan pegawai dalam menyelesaikan pekerjaan tepat waktu, kualitas pekerjaan yang masih rendah serta kemampuan pegawai dalam memecahkan masalah yang dihadapi, selain itu pengawasan juga menjadi faktor penghambat seperti pengetahuan akan penggunaan aplikasi komputer yang masih sedikit serta faktor mootivasi kerja pegawai seperti semangat pegawai yang rendah dalam pelaksanaan tugas rutinitasnya.

Dari fenomena yang didapat diatas, peneliti mengambil contoh mengenai produktivitas kerja yang rendah terkait dengan tingkat ratarata keterlambatan seluruh pegawai yang cukup tinggi yaitu 24 menit setiap harinya. Hal ini patut menjadi perhatian dalam upaya peningkatan produktivitas kerja pegawai.

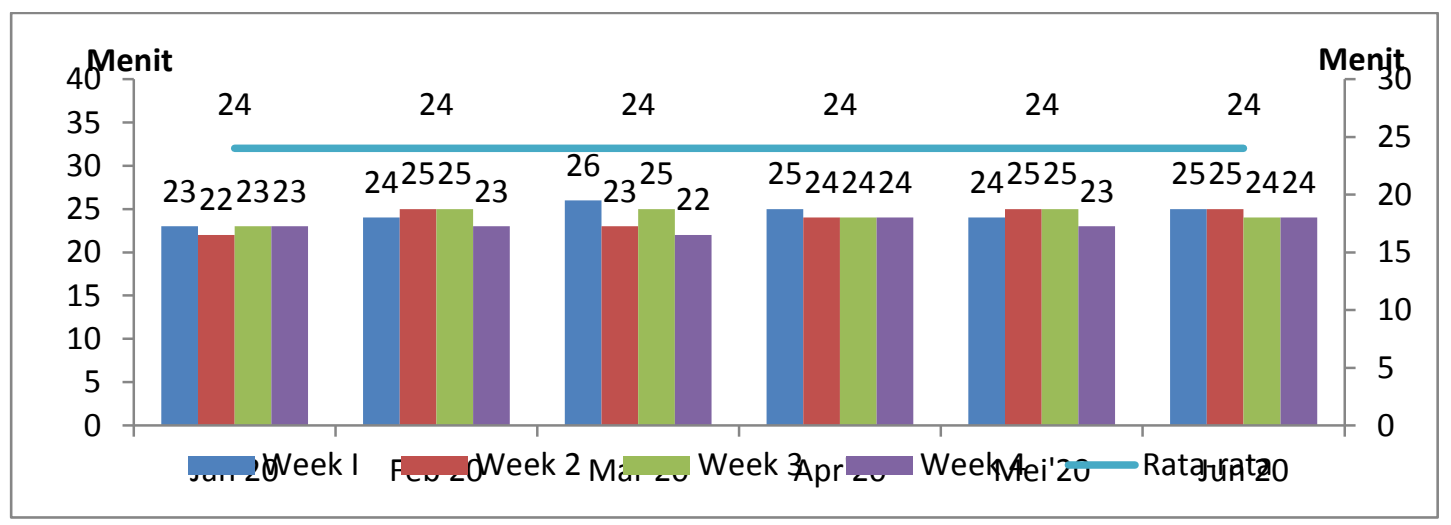

Gambar 1. Tingkat Keterlambatan pegawai.

Sumber: Dinas Perpustakaan Dan Kearsipan Kota Tanjungbalai-2019

\subsection{Rumusan Masalah}

Setiap lembaga atau instanasi pasti mempunyai masalah yang berbeda-beda dengan lembaga lainnya. Adanya perubahan yang selalu dihadapi oleh setiap organisasi baik yang berada diluar maupun didalam organisasi tersebut dapat menjadi hambatan demi pencapaian tujuan yang efektif dan efisien.

Berdasarkan latar belakang masalah tersebut diatas, maka yang menjadi rumusan masalah dalam penelitian ini adalah:
1) Apakah pemberdayaan aparatur secara parsial berpengaruh positif dan signifikan terhadap produktivitas kerja pegawai Dinas Perpustakaan Dan Kearsipan Kota Tanjungbalai.

2) Apakah pengawasan secara parsial berpengaruh positif dan signifikan terhadap produktivitas kerja pegawai Dinas Perpustakaan Dan Kearsipan Kota Tanjungbalai.

3) Apakah lingkungan kerja secara parsial berpengaruh positif dan signifikan terhadap 
produktivitas

Perpustakaan

kerja

pegawai

Dinas

Tanjungbalai.

4) Apakah pemberdayaan aparatur, pengawasan dan lingkungan kerja secara simultan berpengaruh positif dan signifikan terhadap produktivitas kerja pegawai Dinas Perpustakaan Dan Kearsipan Kota Tanjungbalai.

\subsection{Batasan Masalah}

Agar permasalahan yang dikaji terarah maka permasalahan dibatasi sebagai berikut. Penelitian ini akan mengkaji produktivitas kerja pegawai namun dalam penelitian ini hanya membahas pengaruh pemberdayaan aparatur, pengawasan dan lingkungan kerja yang berdampak ataupun tidak berdampak terhadap produktivitas kerja pegawai Dinas Perpustakaan Dan Kearsipan Kota Tanjungbalai.

\subsection{Hioptesis}

Berdasarkan rumusan masalah, tujuan penelitian, kajian teori, dan kerangka

konseptual yang telah dikemukakan diatas, maka rumusan hipotesis penelitian ini dapat dirumuskan sebagai berikut:

1) Pemberdayaan aparatur secara parsial berpengaruh positif dan signifikan terhadap produktivitas kerja pegawai Dinas Perpustakaan Dan Kearsipan Kota Tanjungbalai.

2) Pengawasan secara parsial berpengaruh positif dan signifikan terhadap produktivitas kerja pegawai Dinas Perpustakaan Dan Kearsipan Kota Tanjungbalai.

3) Lingkungan kerja secara parsial berpengaruh positif dan signifikan terhadap produktivitas kerja pegawai Dinas Perpustakaan Dan Kearsipan Kota Tanjungbalai.

4) Pemberdayaan aparatur, pengawasan dan lingkungan kerja secara simultan berpengaruh positif dan signifikan terhadap produktivitas kerja pegawai Dinas Perpustakaan Dan Kearsipan Kota Tanjungbalai.

\subsection{Tujuan Penelitian}

Penelitian ini bertujuan untuk mengetahui dan menganalisis pengaruh pemberdayaan aparatur, pengawasan dan lingkungan kerja terhadap produktivitas kerja pegawai Dinas Perpustakaan Dan Kearsipan Kota Tanjungbalai baik secara simultan maupun parsial, serta mencari hubungan atau pengaruh setiap variabel seperti:

1) Untuk mengetahui pengaruh pemberdayaan aparatur terhadap produktivitas kerja pegawai Dinas Perpustakaan Dan Kearsipan Kota Tanjungbalai.

2) Untuk mengetahui pengaruh pengawasan terhadap produktivitas kerja pegawai Dinas Perpustakaan Dan Kearsipan Kota Tanjungbalai.

3) Untuk mengetahui pengaruh lingkungan kerja terhadap produktivitas kerja pegawai Dinas Perpustakaan Dan Kearsipan Kota Tanjungbalai.

4) Untuk mengetahui pengaruh pemberdayaan aparatur, pengawasan dan lingkungan kerja terhadap produktivitas kerja pegawai Dinas Perpustakaan Dan Kearsipan Kota Tanjungbalai.

\section{Metode Penelitian}

\subsection{Populasi}

Populasi adalah sekumpulan objek yang menjadi pusat perhatian, yang padanya terkandung informasi yang ingin diketahui. Objek ini disebut dengan satuan analisis. Satuan analisis ini memiliki kesamaan perilaku atau karakteristik yang ingin diteliti. Menurut Arikunto (2013: 173) populasi adalah keseluruhan dari subjek penelitian. Jadi yang dimaksud populasi adalah individu yang memiliki sifat yang sama walaupun prosentase kesamaan itu sedikit, atau dengan kata lain seluruh individu yang akan dijadikan sebagai obyek penelitian. Sedangkan Sugiyono (2013: 117) populasi adalah generalisasi yang terdiri atas obyek/ subyek yang mempunyai kualitas dan karakteristik tertentu yang ditetapkan oleh peneliti untuk dipelajari dan kemudian ditarik kesimpulannya.

Maka yang menjadi populasi dalam penelitian ini adalah seluruh pegawai Dinas Perpustakaan Dan Kearsipan Kota Tanjungbalai yang berjumlah 40 orang dengan rincian sebagai berikut:

Tabel 1. Kerangka Populasi

\begin{tabular}{|c|l|r|}
\hline No & Golongan & Jumlah \\
\hline 1 & Pembina & 5 \\
\hline 2 & Penata & 16 \\
\hline 3 & Pengatur & 6 \\
\hline 4 & Honorer & 13 \\
\hline & Total & $\mathbf{4 0}$ \\
\hline
\end{tabular}

Sumber: Dinas Perpustakaan Dan Kearsipan Kota Tanjungbalai -2020 


\subsection{Sampel}

Sampel merupakan contoh atau himpunan bagian (subset) dari suatu populasi yang dianggap mewakili populasi tersebut sehingga informasi apa pun yang dihasilkan oleh sampel ini bisa dianggap mewakili keseluruhan populasi. Arikunto (2013: 174) berpendapat bahwa sampel adalah sebagian atau wakil populasi yang diteliti. Sedangkan menurut Sugiyono (2013: 118) sampel adalah bagian dari jumlah dan karakteristik yang dimiliki oleh populasi tersebut.

Teknik pengambilan sampel merupakan sebuah proses penyeleksian jumlah dari populasi untuk dapat mewakili populasi. Teknik pengambilan sampel adalah berbagai cara yang ditempuh untuk pengambilan sampel agar mendapatkan sampel yang benar-benar sesuai dengan seluruh subjek penelitian tersebut (Nursalam, 2013: 113).
Pengambilan sampel dalam penelitian ini adalah dengan cara Non Probabilty Sampel atau pengambilan sampel tidak Random mengingat keterbatasan jumlah populasi pada objek peneltian. Teknik pengambilan sampel pada penelitian ini adalah total sampling. Total sampling adalah teknik pengambilan sampel dimana jumlah sampel sama dengan populasi (Sugiyono, 2013: 76). Alasan mengambil total sampling karena menurut Sugiyono (2013: 77) jumlah populasi yang kurang dari 100, seluruh populasi dijadikan sampel penelitian semuanya.

Berkaitan dengan judul penelitian yang diambil, maka sampel dalam penelitian ini adalah seluruh pegawai Dinas Perpustakaan Dan Kearsipan Kota Tanjungbalai yang berjumlah 38 orang dengan rincian sebagai berikut:

Tabel 2. Kerangka Sampel

\begin{tabular}{|c|l|c|c|l|}
\hline No & Golongan & Populasi & Sampel & \multicolumn{1}{c|}{ Keterangan } \\
\hline 1 & Pembina & 5 & 4 & 1 Orang Merupakan Pimpinan \\
\hline 2 & Penata & 16 & 15 & 1 Orang Merupakan Peneliti \\
\hline 3 & Pengatur & 16 & 16 & - \\
\hline 4 & Honorer & 13 & 13 & - \\
\hline \multicolumn{2}{|c|}{ Total } & $\mathbf{4 0}$ & $\mathbf{3 8}$ & \\
\hline
\end{tabular}

Sumber: Dinas Perpustakaan Dan Kearsipan Kota Tanjungbalai -2020

\subsection{Uji Normalitas}

Pengujian normalitas data bertujuan untuk melihat normal tidaknya sebaran data yang akan dianalisis. Model regresi yang baik adalah distribusi normal atau mendekati normal. Untuk melihat normalitas data ini digunakan pendekatan grafik yaitu Normality Probability Plot.

Deteksi normalitas dengan melihat penyebaran data (titik) pada sumbu diagonal dari grafik. Menurut Sugiyono (2013: 354), dasar pengambilan keputusan adalah:

a. Jika data menyebar disekitar garis diagonal dan mengikuti arah garis diagonal, maka model regresi memenuhi asumsi normalitas.

b. Jika data menyebar jauh dari garis diagonal dan atau tidak mengikuti arah garis diagonal, maka model regresi tidak memenuhi asumsi normalitas.

Pada output SPSS bagian normal P-P Plot of Regresion Standardized Residual, dapat dijelaskan bahwa data-data (titik-titik) cenderung lurus mengikuti garis diagonal sehingga data dalam penelitian ini cenderung berdistribusi normal, seperti terlihat pada gambar dibawah ini.

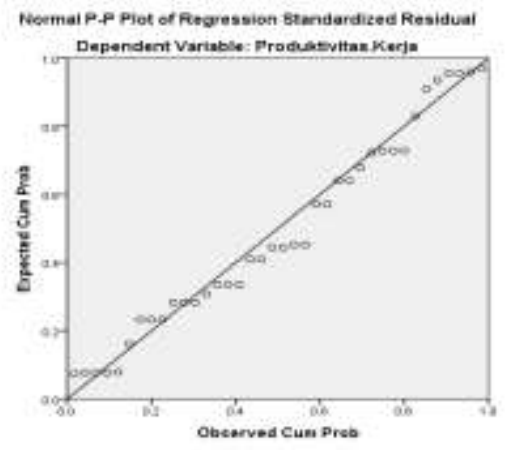

Gambar 2. Normalitas Data

\subsection{Uji Multikolinearitas}

Pengujian multikolinearitas dilakukan untuk melihat apakah pada model regresi ditemukan adanya korelasi antara variabel bebas. Jika terjadi korelasi, maka dinamakan terdapat problem multikolinearitas. Cara mendeteksinya adalah dengan melihat nilai Variance Inflation Factor (VIF). Menurut Sugiyono (2013: 354), pada umumnya jika VIF lebih besar dari 5, maka variabel bebas tersebut mempunyai persoalan multikolinearitas dengan variabel bebas lainnya. 
Pada ouput SPSS bagian Coefficient, menunjukan tidak terjadi multikolinearitas, semua angka VIF berada dibawah 5, hal ini seperti dapat dilihat pada tabel dibawah ini.

Coefficients $^{\mathrm{a}}$

Tabel 3. Uji Multikolinearitas

\begin{tabular}{|ll|l|l|}
\hline \multirow{2}{*}{ Model } & & \multicolumn{2}{|l|}{ Collinearity Statistics } \\
\cline { 3 - 4 } & (Constant) & Tolerance & VIF \\
\hline \multirow{4}{*}{1} & Pemberdayaan.Aparatur & .618 & \\
& Pengawasan & .638 & 1.618 \\
& Lingkungan.Kerja & .864 & 1.566 \\
\end{tabular}

a. Dependent Variable: Produktivitas kerja

\subsection{Uji Heteroskedastisitas}

Pengujian heteroskedastisitas bertujuan untuk melihat apakah dalam sebuah model regresi terjadi ketidaksamaan varians dari residual yang merupakan suatu pengamatan ke pengamatan yang lainnya. Jika varians dari residual yang merupakan suatu pengamatan ke pengamatan yang lain bernilai tetap, maka hasil data disebut homoskedastisitas dan jika varians berbeda atau bernilai tidak tetap maka disebut heteroskedastisitas. Model regresi yang baik adalah model yang bernilai tetap atau homoskedastisitas atau tidak terjadi heteroskedastisitas.

Deteksi heteroskedastisitas dilakukan dengan cara melihat ada tidaknya pola tertentu pada data yang diolah. Menurut Sugiyono (2013: 354), dasar pengambilan keputusannya adalah:

a. Jika pola tertentu seperti titik-titik yang ada membentuk suatu pola tertentu yang teratur, maka terdapat situasi heteroskedastisitas.

b. Jika tidak ada pola yang jelas, serta titik-titik menyebar diatas dan dibawah angka nol pada sumbu Y, maka tidak terjadi heteroskedastisitas.

Pada output SPSS dibagian Scatrerplot, terlihat titk-titik menyebar secara acak, tidak membentuk sebuah pola tertentu yang jelas, serta tersebar baik diatas maupun dibawah angka nol pada sumbu Y. Hal ini berarti tidak terjadi hetorskedastisitas pada model regresi, sehingga model regresi layak dipakai. Pola Scatterplot dapat dilihat pada gambar dibawah ini.

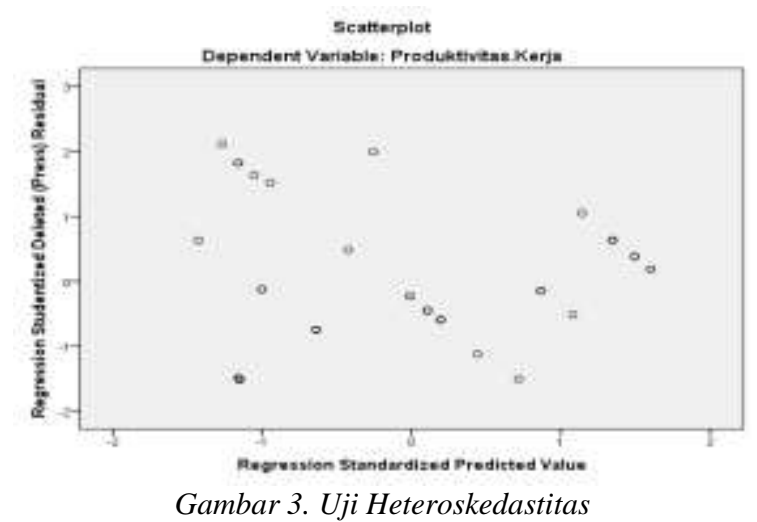

\section{Evaluasi Data}

\subsection{Pengujian Hipotesis}

Dalam evaluasi data ini penulis akan melakukan pengujian hipotesis, baik secara partial ataupun secara simultan. Selanjutnya untuk mempermudah dalam evaluasi data ini, maka penulis mencari niali-nilai yang dibutuhkan dengan menggunakan perangkat lunak komputer yaitu program SPSS V.26.00 for windows dengan hasil data sebagai berikut:

Tabel 4. Hasil Uji Statistik Keofesien Regresi

\begin{tabular}{|c|c|c|c|c|c|}
\hline \multirow[t]{2}{*}{ Model } & \multicolumn{2}{|c|}{$\begin{array}{l}\text { Unstandardized } \\
\text { Coefficients }\end{array}$} & $\begin{array}{l}\text { Standardized } \\
\text { Coefficients }\end{array}$ & \multirow[t]{2}{*}{$\mathrm{t}$} & \multirow[t]{2}{*}{ Sig. } \\
\hline & B & Std. Error & Beta & & \\
\hline (Constant) & 4.577 & 4.409 & & 1.038 & .307 \\
\hline $\begin{array}{l}\text { Pemberdayaan.Aparat } \\
\text { ur }\end{array}$ & .286 & .108 & 287 & 2.644 & .012 \\
\hline Pengawasan & .392 & .082 & .511 & 4.787 & .000 \\
\hline Lingkungan.Kerja & .276 & 086 & .295 & 3.219 & .003 \\
\hline
\end{tabular}

a. Dependent Variable: Produktivitas kerja 
Berdasarkan tabel 4 diatas dapat dibuat persamaan regresi sebagai berikut:

$Y=4,577+0,286 X_{1}+0,392 X_{2}+0,276 X_{3}+\varepsilon$

Persamaan diatas dijelaskan bahwa koefesien $\mathrm{X}_{1} \quad$ (pemberdayaan aparatur) mempunyai nilai positif yaitu 0.286 , hal ini menunujukan bahwa variabel pemberdayaan aparatur mempunyai pengaruh positif terhadap produktivitas kerja pegawai. Jika pemberdayaan aparatur dilakukan secara tepat dan sesuai terhadap pekerkjaan pegawai maka akan berdampak positif terhadap produktivitas kerja pegawai Dinas Perpustakaan Dan Kearsipan Kota Tanjungbalai.

Berdasarkan persamaan diatas bahwa koefesien $\mathrm{X}_{2}$ (pengawasan) juga memiliki nilai positif yaitu 0,392 . Hal ini menunjukan bahwa variabel pengawasan mempunyai pengaruh positif terhadap produktivitas kerja pegawai.

Berdasarkan persamaan diatas bahwa koefesien $\mathrm{X}_{3}$ (fasilitas pekerjaan) juga memiliki nilai positif yaitu 0,276 . Hal ini menunjukan bahwa variabel fasilitas pekerjaan mempunyai pengaruh positif terhadap produktivitas kerja pegawai.

Hal ini berarti jika pemberdayaan aparatur yang dilakukan terhadap pekerjaan pegawai sudah sesuai, pengawasan yang selalu dilakukan terhadap pegawai dan fasilitas yang yang disediakan sudah sesuai dengan kebutuhan pegawai maka akan berdampak positif terhadap produktivitas kerja pegawai di Dinas Perpustakaan Dan Kearsipan Kota

Tanjungbalai.

\subsection{Pengujian Secara Simultan (Uji F)}

Hasil pengujian hipotesis pengaruh pemberdayaan aparatur, pengawasan dan fasilitas pekerjaan terhadap produktivitas kerja pegawai dapat dilihat pada tabel dibawah ini.

Tabel 5. Hasil Uji Statistik Secara Simultan

\begin{tabular}{|ll|l|l|l|l|l|}
\hline \multicolumn{2}{|c|}{ Model } & Sum of Squares & df & Mean Square & F & Sig. \\
\hline \multirow{4}{*}{$\begin{array}{ll}\text { 1 } \\
\text { Regression }\end{array}$} & 42.970 & 3 & 14.323 & 34.580 & $.000^{\mathrm{b}}$ \\
& \begin{tabular}{l} 
Residual \\
\multicolumn{2}{|c|}{ Total }
\end{tabular} & 14.083 & 34 & .414 & & \\
\hline
\end{tabular}

a. Dependent Variable: Produktivitas.Kerja

b. Predictors: (Constant), Lingkungan.Kerja, Pengawasan, Pemberdayaan.Aparatur

Pada tabel 5 diatas terlihat bahwa nilai $\mathrm{F}_{\text {hitung }}$ adalah 34,580 dan nilai signifikansi $0,000^{\mathrm{b}}$. Diketahui nilai $\mathrm{F}_{\text {tabel }}$ dengan tingkat kepercayaan $95 \%(\alpha: 0,05)$ adalah 2,870 . Oleh karena itu nilai $F_{\text {hitung }}>F_{\text {tabel }}(34,580>2,870)$ maka $\mathrm{H}_{\mathrm{o}}$ ditolak dan menerima $\mathrm{H}_{\mathrm{a}}$ hipotesis dalam penelitian ini yaitu bahwa pemberdayaan aparatur, pengawasan dan lingkungan kerja secara simultan berpengaruh positif dan signifikan terhadap produktivitas kerja pegawai Dinas Perpustakaan Dan Kearsipan Kota Tanjungbalai.

\subsection{Pengujian Secara Parsial (Uji t)}

a. Pengaruh Pemberdayaan aparatur Terhadap Produktivitas kerja Pegawai Tabel 6. Hasil Uji Parsial Variabel $\mathrm{X}_{1}$ Terhadap Y

\begin{tabular}{|ll|r|r|r|r|r|}
\hline \multirow{2}{*}{ Model } & \multicolumn{2}{|c|}{$\begin{array}{c}\text { Unstandardized } \\
\text { Coefficients }\end{array}$} & $\begin{array}{c}\text { Standardized } \\
\text { Coefficients }\end{array}$ & \multirow{2}{*}{ Sig. } & \\
\cline { 2 - 5 } & \multicolumn{1}{|c|}{ B } & Std. Error & \multicolumn{1}{c|}{ Beta } & & \\
\hline 1 & Pemberdayaan.Aparatur & .286 & .108 & .287 & 2.644 & .012 \\
\hline
\end{tabular}

Sumber: Out Put SPSS Data Diolah-2020

Untuk mengetahui secara partial pengaruh pemberdayaan aparatur terhadap produktivitas kerja pegawai dapat dilihat pada tebel 6 diatas. Berdasarkan tabel tersebut diperoleh nilai $t_{\text {hitung }}$ sebesar 2,644 dan nilai signifikansi 0,012. Sedangkan nilai $t_{\text {tabel }}$ pada tingkat kepercayaan 95\% $(\alpha: 0,05)$ adalah 2,021. Oleh karena itu nilai $t_{\text {hitung }}>t_{\text {tabel }}(2,644>2,021)$ maka $H_{o}$ ditolak dan menerima $\mathrm{H}_{\mathrm{a}}$ hipotesis dalam penelitian ini yaitu variabel pemberdayaan aparatur secara parsial berpengaruh positif dan signifikan terhadap produktivitas kerja pegawai Dinas Perpustakaan Dan Kearsipan Kota Tanjungbalai.

\section{b. Pengaruh Pengawasan Terhadap Produktivitas kerja Pegawai}


Tabel 7. Hasil Uji Parsial Variabel $\mathrm{X}_{2}$ Terhadap $\mathrm{Y}$

\begin{tabular}{|c|l|l|l|l|l|}
\hline \multirow{2}{*}{ Model } & \multicolumn{2}{|l|}{$\begin{array}{l}\text { Unstandardized } \\
\text { Coefficients }\end{array}$} & $\begin{array}{l}\text { Standardized } \\
\text { Coefficients }\end{array}$ & t & \multirow{2}{*}{} \\
\cline { 2 - 5 } & $\mathrm{B}$ & Std. Error & Beta & & \\
\hline Lingkungan.Kerja & .392 & .082 & .511 & 4.787 & .000 \\
\hline
\end{tabular}

Sumber: Out Put SPSS Data Diolah-2020

Untuk mengetahui secara partial pengaruh pengawasan terhadap produktivitas kerja pegawai dapat dilihat pada tabel 7 diatas. Berdasarkan tabel tersebut diperoleh nilai $t_{\text {hitung }}$ sebesar 4,787 dan nilai signifikansi 0,000. Sedangkan nilai $\mathrm{t}_{\text {tabel }}$ pada tingkat kepercayaan 95\% $(\alpha: 0,05)$ adalah 2,021. Oleh karena itu nilai $t_{\text {hitung }}>t_{\text {tabel }}(4,787>2,021)$ maka $H_{o}$ ditolak dan menerima $\mathrm{H}_{\mathrm{a}}$ hipotesis dalam

penelitian ini yaitu variabel pengawasan secara parsial berpengaruh positif dan signifikan terhadap produktivitas kerja pegawai Dinas Perpustakaan Dan Kearsipan Kota Tanjungbalai.

\section{c. Pengaruh Lingkungan kerja Terhadap Produktivitas kerja Pegawai}

Tabel 8. Hasil Uji Parsial Variabel $\mathrm{X}_{3}$ Terhadap $\mathrm{Y}$

\begin{tabular}{|c|l|l|l|l|l|}
\hline \multirow{2}{*}{ Model } & \multicolumn{2}{|l|}{$\begin{array}{l}\text { Unstandardized } \\
\text { Coefficients }\end{array}$} & $\begin{array}{l}\text { Standardized } \\
\text { Coefficients }\end{array}$ & \multirow{2}{*}{ Sig. } \\
\cline { 2 - 5 } & B & Std. Error & Beta & \\
\hline Fasilitas pekerjaan & .276 & .086 & .295 & 3.219 & .003 \\
\hline
\end{tabular}

Sumber: Out Put SPSS Data Diolah-2020

Untuk mengetahui secara partial pengaruh fasilitas pekerjaan terhadap produktivitas kerja pegawai dapat dilihat pada tabel 8 diatas. Berdasarkan tabel tersebut diperoleh nilai $t_{\text {hitung }}$ sebesar 3,219 dan nilai signifikansi 0,003. Sedangkan nilai $\mathrm{t}_{\text {tabel }}$ pada tingkat kepercayaan $95 \%(\alpha: 0,05)$ adalah 2,021. Oleh karena itu nilai $t_{\text {hitung }}>t_{\text {tabel }}(3,219>2,021)$ maka $H_{o}$ ditolak dan menerima $\mathrm{H}_{\mathrm{a}}$ hipotesis dalam penelitian ini yaitu variabel lingkungan kerja secara parsial berpengaruh positif dan

signifikan terhadap produktivitas kerja pegawai Dinas Perpustakaan Dan Kearsipan Kota Tanjungbalai.

\subsection{Uji Koefisien Determinasi $\left(\mathbf{R}^{2}\right)$}

Uji determinan adalah untuk mengetahui seberapa besar pengaruh variabel independent terhadap variabel dependent. Untuk melihat hasil uji determinan maka dapat diketahui nili $\mathrm{R}$ Square atau koefesien determinasi dan dapat dilihat dibawah ini.

Tabel 5.18. Model Summary

\begin{tabular}{|l|l|l|l|l|}
\hline Model & R & R Square & Adjusted R Square & Std. Error of the Estimate \\
\hline 1 & $.868^{\mathrm{a}}$ & .753 & .731 & .644 \\
\hline
\end{tabular}

Sumber: Out Put SPSS Data Diolah-2020
Nilai R Square pada tabel diatas adalah 0,753. Hal ini menunjukan bahwa $75,3 \%$ variabel produktivitas kerja pegawai Dinas Perpustakaan Dan Kearsipan Kota Tanjungbalai dijelaskan oleh variabel pemberdayaan aparatur, pengawasan dan fasilitas pekerjaan, sedangkan sisanya sebesar $24,7 \%$ tidak dilakukan penelitian.

\section{Kesimpulan}

1) Pemberdayaan aparatur secara parsial berpengaruh positif dan signifikan terhadap produktivitas kerja pegawai Dinas Perpustakaan Dan Kearsipan Kota Tanjungbalai.

2) Pengawasan secara parsial berpengaruh positif dan signifikan terhadap produktivitas kerja pegawai Dinas Perpustakaan Dan Kearsipan Kota Tanjungbalai.

3) Lingkungan kerja secara parsial berpengaruh positif dan signifikan terhadap produktivitas kerja pegawai Dinas Perpustakaan Dan Kearsipan Kota Tanjungbalai.

4) Pemberdayaan aparatur, pengawasan dan lingkungan kerja secara simultan berpengaruh positif dan signifikan terhadap produktivitas kerja pegawai Dinas Perpustakaan Dan Kearsipan Kota Tanjungbalai.

5) Nilai R Square pada hasil penelitian ini adalah 0,753. Hal ini menunjukan bahwa 
75,3\% variabel produktivitas kerja pegawai Dinas Perpustakaan Dan Kearsipan Kota Tanjungbalai dijelaskan oleh variabel pemberdayaan aparatur, pengawasan dan fasilitas pekerjaan, sedangkan sisanya sebesar $24,7 \%$ tidak dilakukan penelitian.

\section{DAFTAR PUSTAKA}

Ahmad Fikri Hadin (2013). Eksistensi Badan Pengawasan Keuangan dan Pembangunan di Era Otonomi Daerah. Yogyakarta: Genta Press.

Arikunto, S (2016). Prosedur Penelitian Suatu Pendekatan Praktik. Jakarta: Rineka Cipta.

Ernie dan Saefulah (2015). Pengantar Mananjemen. Jakarta: Murai Kencana.

Gie, The Liang (2010). Administrasi Perkantoran. Yogyakarta: Modern Liberty.

HAW Widjaja (2015). Administrasi Kepegawaian Suatu Pengantar. Jakarta: Raja Grafindo Persada.

Ihyaul Ulum (2019). Intellectual Capital: Konsep Dan kajian Empiris. Yogyakarta: Graha Ilmu.

Iskandar (2018). Metodologi Penelitian Pendidikan dan Sosial (Kuantitatif dan. Kualitatif). Jakarta: Raja Grafindo Persada.

Jemmy (2013). Pengaruh Warna Interior Kantor Terhadap Kinerja. [online]: http://www.eds.com:134/crebin/g:html.

Koswara, E (2010). Menyongsong Pelaksanaan Otonomi daerah Berdasarkan Undangundang Nomor 22 Tahun 1999: Suatu Talahan dan Menyangkut Kebijakan 1- Pelaksanaan dan Kompleksitasnya,. . .

Lewa dan Subowo (2015). Pengaruh Kepemimpinan, Lingkungan Kerja Fisik, dan Kompensasi Terhadap Kinerja Karyawan Di PT. Pertamina(PERSERO) Daerah Operasi Hulu Jawa Bagian Barat. Cirebon: Sinergi Edisi Khusus on Human Resources.
Makmur, Syarif (2017). Pemberdayaan SDM dan Efektivitas Organisasi. Jakarta: Raja Grafindo Persada.

Maman Ukas (2014). Manajemen Konsep, Prinsip Dan Aplikasi.Cetakan ketiga Bandung: AGNINI.

Mangkunegara (2017). MSDM Evaluasi Kinerja Sumber Daya Manusia. Bandung: Remaja Rosdakarya.

Manullang (2011). Manajemen Pengantar Ekonomi Perusahaan, Edisi Revisi, Cetakan Ke Enam Belas. Yogyakarta: BPFE, Yogyakarta.

Maurits, Setyawati (2010). Selintas tentang kelelahan kerja. Yogyakarta: Amara Books.

Nasution, Fuad Abdillah (2013). Analisis Pengaruh Lingkungan Kerja Dan Insentif Terhadap Produktivitas Kerja Karyawan Di Pabrik Kelapa Sawit PT. Perkebunan Nusantara IV Kebun Air Batu Asahan.Tesis Medan: FE USU.

Nitisemito, Alex. S (2010). Manajemen Personalia: Manajemen Sumber. Daya Manusia.Edisi 3 Jakarta: Ghalia Indonesia.

Nursalam (2013). Metodologi Penelitian Ilmu Penellitian. Jakarta: Salemba Medika.

Oktoviyanto, Teguh (2016). Hubungan kelelahan kerja terhadap produktivitas kerja Karyawan Perpustakaan Kota Surabaya.Tesis Surabaya: UIN Sunan Ampel.

Sarundajang (2017). Arus Balik Kekuasaan Pusat dan Daerah. Jakarta: Pustaka Sinar Harapan.

Saydam, Gouzali (2010). Manajemen Sumber Daya Manusia: Suatu Pendekatan Mikro. Jakarta: Djambatan.

Sedarmayanti (2013). Manajemen Sumber Daya Manusia Reformasi Birokrasi dan Manajemen Pegawai Negeri Sipil. Bandung: Mandar Maju.

(2011). Sumber Daya manusia dan Produktivitas Kerja. Jakarta: Mandar Maju.

Siagian, P Sondang (2016). Organisasi Kepemimpinan dan Perilaku Administrasi. Jakarta: Gunung Agung. 